\title{
The Influence of Stress on Professional Satisfaction of Multigrade Teachers: Evidence from the Philippines
}

\author{
Erwin E. Rotas \\ Teacher I, Department of Education \\ General Santos City 9500, Philippines \\ E-mail: erwin.rotas@deped.gov.ph \\ ORCID ID: 0000-0002-1765-2684
}

\begin{abstract}
Teaching is considered a multifarious task. Teachers, in the pursuit of educational success, are burdened with numerous teaching workloads and dilemmas causing them stress. This study endeavored to determine the influence of stress on professional satisfaction of multigrade teachers. It employed correlation research design involving thirty (30) purposively selected multigrade teachers in the Schools Division of General Santos City (GSC), Southern Philippines. Employing the survey method, tailored questionnaires were utilized to gather the needed data. The statistical tools employed in the analysis were weighted mean and Pearson Product Moment Correlation Coefficient. Moderate level of stress and high level of professional satisfaction are gained among the multigrade teachers surveyed. It was further found out that there is no significant relationship between stress and professional satisfaction, providing evidence that stress may not necessarily influence satisfaction. This result offers unique implications in theory, practice, and research which are discussed in the study.
\end{abstract}

Keywords: stress, professional satisfaction, multigrade

\section{Introduction}

In general, teaching refers to passing of ideas, skills and desirable attitudes to the students. It is considered as one of the challenging field of endeavors which necessitates multitasking skills to cope with the difficulties. Multifaceted tasks of teachers comprise curriculum and lesson planning and development, student behavior management, utilization of multiteaching strategies, management of pupils' behavior and preparation of instructional devices.

Morgan and Craith (2015) supports such argument that teachers as dispensers of knowledge are undeniably exposed to heavy teaching workloads causing them stress. Stress is often the outcome of classroom experiences particularly the heightening challenge of unruly behavior of pupils. It can be further noted that workload stress brings influence on many aspects of the teaching condition such as cognitive achievement (Day, Sammons, Stobart, Kington \& $\mathrm{Gu}, 2007$ ), school motivation (Morgan \& Craith, 2015), and results-based performance (Rotas \& Cahapay, 2020).

Based on theory of Weiss and Copranzano (1996), affective events such as emotions, mental states and responses to occurrences that transpire in workplace cause psychological strains and result to dissatisfaction. It further explained that work behaviors affiliated to affective domain shown by an employee's internal influences including emotions, specifically behaviors anchored on cognition are best predictors of the level of satisfaction. Shann (1998) as cited by Tehseen and Ul Hadi (2015) emphasized the importance of teachers' professional satisfaction for a transformative educational reform. 
A synthesis of related scholarly works on the correlation of two variables uncovered that there is a significant relationship between stress and satisfaction (Kaur, 2011; Wang, 2012; Parsa, Alizadeh \& Kasraie, 2013; De Nobile, John \& Mc Cormick, 2005; Kayastha, \& Kayastha, 2012). On the other hand, studies of Necsoi (2011), Chaplain (1995), Schwarzer and Hallum (2008) concluded negative correlation between stress and professional satisfaction. Despite results of high levels of teachers' stress in their respective workplaces, still many teachers find personal satisfaction towards their profession. Past scholarly works on teachers' stress and satisfaction though many, have literature gaps.

Most studies probed on the stress of regular elementary teachers (e.g. Roxas, 2009; Asaloei, Wolomasi \& Werang, 2020; Harish \& Prabha, 2019; and Kyriacou \& Chien, 2004;); no recorded studies as far as this paper is concerned probed on the stress particularly of multigrade teachers. Multigrade classrooms require a single teacher to manage pupils of more than one grade level in only one classroom because of lack of learning resources and learning infrastuctures (Little, Pridmore, Bajracharya \& Vithanaphathivana, 2007). Lesson and curriculum implementation can also be very difficult and time consuming for teachers in this setting (Msimanga, 2019). Despite these pressures, multigrade teachers are expected to practice wise classroom management techniques in the delivery of lessons and use of learning resources and devices twice as much as of regular teachers (Jordaan, 2006). Multigrade settings also raise the issue of diversity of learners and in dealing with students with troublesome behaviors (UNESCO, 2011). Teachers in this setting also need to create experimentations, simulations, and innovations to improve the teaching and learning process (Vicente, 2012). As a result, multigrade teachers encounter more distinctive stressful events compared to the regular teachers in the delivery of quality instruction.

On a positive side, opportunities can be created out of these issues because multigrade schooling can be a key to uplift the living conditions of the children who are economicallydisadvantaged in the society (Enayati, Movahedian \& Zameni, 2016). Multigrade classes also encourage gender equality and greater classroom engagement among pupils. They are also geared to develop high academic motivation and self-esteem (Veenman, 1995). Also, it makes the educational delivery fast and accessible in remote areas (Little, 2004). Hence, it will help increase the chances of educational success in improving the conditions of people in the society.

Tthe study endeavors to contribute to literature by studying the relationship between stress and satisfaction especially in multigrade setting. This scientific undertaking will significantly contribute to theory, practice and research regarding the association of these two equally important variables in the field of teaching. Quality delivery of instruction is believed to be the key foundation of every educational success. Significantly, this study wished to help policymakers and school stakeholders in instituting effective school programs and policies and in making adjustments in the curriculum that will ease the tasks of teachers. Furthermore, it will open doors for opportunities for multigrade schools in terms of provision of facilitative instructional paraphernalia, technologies, and high government funding.

Given these complexities experienced in multigrade settings, a scientific inquiry of the influence of stress on the professional satisfaction of multigrade teachers inspired the researcher to pursue the study. Specifically, this study provided answers the following research questions:

1. What is the level of stress of multigrade teachers?

2. What is the level of professional satisfaction of multigrade teachers?

3. Is there a significant relationship between stress and professional satisfaction of multigrade teachers? 


\section{Theoretical Framework}

This study is primarily anchored on Hierarchy of Needs by Maslow (1943, 1970). This theory proposed an idea that self-actualization can be achieved by a person when he/she reach his or her full potential (motivation). Further, it posits that before growth or self- actualization, the basic needs of the person should be first met. These include physiological and safety or existence needs that are mainly satisfied by material incentives. The needs for shelter, physical well-being and psychological safety as well as provisions are some of these existence needs. Second, love/belonging, and self-esteem or relatedness needs are satisfied by interpersonal relationships and social interaction of the person. It involves open communication and mutual exchange of ideas with other members of an organization. Third, self-actualization or growth needs are the needs to grow and reach the full potential that a person is capable of reaching. Usually these needs are fulfilled by individual involvement in the organizational environment.

It is assumed, based on the given theory that stress is a significant factor that influences professional satisfaction. Thus, this study operationalizes that higher stress leads to lower professional of satisfaction of multigrade teachers. The framework was formed based on the problems presented in the study that endeavors to provide answer on the association between stress and professional satisfaction. With regards to the influence of stress to teacher's professional satisfaction, numerous scholarly works had been published as mentioned in this study.

\section{Research Methodology}

This study employed correlational research design. Correlational study is appropriate for this study because it aimed to measure two variables from the same group of aspects and eventually determine their level of association (Lomax \& Li, 2013).

It involved thirty (30) purposively selected multigrade teachers in selected schools of GSC, Southern Philippines in the school year 2015-2016. These teachers were identified as handling two or more grades according to the Schools Division of GSC (DepEd Gensan Survey Aggregated Data, 2015). They are also experienced in handling multigrade classes because of the workshops and trainings they attended. Most of the teachers are members of tribes in the locality. They were selected despite tribe, age, gender, experience, educational attainment, and rank.

This study was conducted within the context of selected schools in GSC that employ multigrade classes. Most of these schools are located at the remote areas of the city. Multigrade schools in the city were formed because of teacher shortage, distance of home from school, lack of budget for school infrastructures.

Stress Scale (35 items) and Professional Satisfaction Scale (20 items) were utilized to collect the data for this study. The items in the questionnaires were formulated based on the readings of researcher of the literature. These were evaluated by the expert validators to establish content validity. Both obtained a weighted mean of 4.84 which means very highly valid questionnaires. A pilot testing was also administered to ensure reliability. Both questionnaires garnered excellent reliability remarks with a Cronbach's alpha of 0.99 and 0.91 , respectively.

The analysis of gathered data utilized weighted mean, and standard deviation. Five (5) point Likert scale was also used to measure and describe the two variables. Hence, Pearson Product Moment Coefficient Correlation was used to calculate the strength of a linear association between the two variables. All tests were done at 0.05 level of significance. 


\section{Results and Analysis}

Table 1. Stress of Multigrade Teachers

\begin{tabular}{|c|c|c|c|}
\hline Indicators & $\mathbf{W M}$ & Description & $\begin{array}{c}\text { Verbal } \\
\text { Interpretation }\end{array}$ \\
\hline \multicolumn{4}{|l|}{ I am stressed in ....... } \\
\hline 1. demonstrating the value for learning. & 3.07 & Neutral & Moderate \\
\hline $\begin{array}{l}\text { 2. implementing school policies and } \\
\text { procedures. }\end{array}$ & 3.07 & Neutral & Moderate \\
\hline $\begin{array}{l}\text { 3. demonstrating punctuality at going to } \\
\text { school. }\end{array}$ & 3.07 & Neutral & Moderate \\
\hline $\begin{array}{l}\text { 4. maintaining appropriate appearance at } \\
\text { school. }\end{array}$ & 3.27 & Neutral & Moderate \\
\hline $\begin{array}{l}\text { 5. being careful about the effect of my } \\
\text { behaviour on pupils. }\end{array}$ & 3.23 & Neutral & Moderate \\
\hline $\begin{array}{l}\text { 6. creating an environment that promotes } \\
\text { fairness }\end{array}$ & 3.37 & Neutral & Moderate \\
\hline $\begin{array}{l}\text { 7. establishing a safe and conducive to } \\
\text { learning classroom environment }\end{array}$ & 3.27 & Neutral & Moderate \\
\hline $\begin{array}{l}\text { 8. communicating higher learning } \\
\text { expectations to each learner }\end{array}$ & 3.37 & Neutral & Moderate \\
\hline $\begin{array}{l}\text { 9. handling behavior problems quickly and } \\
\text { with due respect to children's rights; and } \\
\text { giving timely feedback to reinforce } \\
\text { appropriate to learners' behaviour. }\end{array}$ & 3.67 & Agree & High \\
\hline $\begin{array}{l}\text { 10. guiding individual learner requiring } \\
\text { development of appropriate social and } \\
\text { learning behavior; and communicating } \\
\text { school policies and procedures for } \\
\text { classroom behavior and seeing to it that } \\
\text { they are followed. }\end{array}$ & 3.27 & Neutral & Moderate \\
\hline $\begin{array}{l}\text { 11. using information on the learning styles } \\
\text { and needs of the learners to design and } \\
\text { select learning experiences and } \\
\text { establishing goals that define appropriate } \\
\text { expectations for all }\end{array}$ & 3.10 & Neutral & Moderate \\
\hline $\begin{array}{l}\text { 12. pacing lessons appropriate to needs and/or } \\
\text { abilities of learners; and providing } \\
\text { differentiated activities for learners. }\end{array}$ & 3.17 & Neutral & Moderate \\
\hline $\begin{array}{l}\text { 13. initiating other learning approaches for } \\
\text { learners whose needs have not been met by } \\
\text { usual approaches; and showing sensitivity } \\
\text { to multi-cultural background of the } \\
\text { learners. }\end{array}$ & 3.27 & Neutral & Moderate \\
\hline $\begin{array}{l}\text { 14. setting clear, challenging and achievable } \\
\text { expectation on the holistic development of } \\
\text { all learners; and identifying learning gaps } \\
\text { and takes action to enable learners to catch } \\
\text { up. }\end{array}$ & 3.13 & Neutral & Moderate \\
\hline
\end{tabular}




\begin{tabular}{|c|c|c|c|}
\hline $\begin{array}{l}\text { 15. employing integrative and interactive } \\
\text { strategies for meaningful and holistic } \\
\text { development of learners; being sensitive to } \\
\text { unusual behavior of learners and taking } \\
\text { appropriate action; and providing } \\
\text { opportunities to enhance learners growth in } \\
\text { all aspects. }\end{array}$ & 3.17 & Neutral & Moderate \\
\hline $\begin{array}{l}\text { 16. delivering accurate and updated content } \\
\text { knowledge using appropriate } \\
\text { methodologies, approaches and strategies } \\
\text { and integrating language, literacy and } \\
\text { quantitative skill development and values } \\
\text { in the subject areas. }\end{array}$ & 3.20 & Neutral & Moderate \\
\hline $\begin{array}{l}\text { 17. aligning lesson objectives with the } \\
\text { teaching methods, learning activities and } \\
\text { instructional materials or resources } \\
\text { appropriate to learners and integrating } \\
\text { relevant scholarly works and ideas to } \\
\text { enrich the lesson. }\end{array}$ & 3.13 & Neutral & Moderate \\
\hline $\begin{array}{l}\text { 18. communicating clear learning goals for the } \\
\text { lessons that are appropriate for learners. }\end{array}$ & 2.97 & Neutral & Moderate \\
\hline $\begin{array}{l}\text { 19. implementing the curriculum to promote } \\
\text { holistic development of the learners. }\end{array}$ & 3.20 & Neutral & Moderate \\
\hline $\begin{array}{l}\text { 20. selecting teaching methods, learning } \\
\text { activities and instructional materials or } \\
\text { resources appropriate to learners and } \\
\text { aligned to objectives of the lesson. }\end{array}$ & 3.53 & Agree & High \\
\hline $\begin{array}{l}\text { 21. communicating promptly and clearly the } \\
\text { learners' progress to parents, superiors and } \\
\text { to learners themselves. }\end{array}$ & 3.27 & Neutral & Moderate \\
\hline $\begin{array}{l}\text { 22. preparing formative and summative tests } \\
\text { and employing non-traditional assessment } \\
\text { techniques (portfolio, authentic } \\
\text { performance, journals, rubrics, etc.) }\end{array}$ & 3.43 & Neutral & Moderate \\
\hline $\begin{array}{l}\text { 23. interpreting and using assessment results to } \\
\text { improve teaching and learning and } \\
\text { identifying teaching-learning difficulties } \\
\text { and their possible causes to address gaps. }\end{array}$ & 3.33 & Neutral & Moderate \\
\hline $\begin{array}{l}\text { 24. providing timely and accurate feedback to } \\
\text { learners to encourage them to reflect on } \\
\text { and monitor their own learning growth. }\end{array}$ & 3.37 & Neutral & Moderate \\
\hline $\begin{array}{l}\text { 25. keeping accurate records of grades with } \\
\text { performance levels of learners. }\end{array}$ & 3.23 & Neutral & Moderate \\
\hline $\begin{array}{l}\text { 26. involving community in sharing } \\
\text { accountability for the learners' } \\
\text { achievement. }\end{array}$ & 3.17 & Neutral & Moderate \\
\hline $\begin{array}{l}\text { 27. using community human and materials } \\
\text { resources to support learning. }\end{array}$ & 3.43 & Neutral & Moderate \\
\hline $\begin{array}{l}\text { 28. using the community as a laboratory for } \\
\text { learning. }\end{array}$ & 3.20 & Neutral & Moderate \\
\hline
\end{tabular}




\begin{tabular}{|l|c|c|c|}
\hline $\begin{array}{l}\text { 29. participating in community activities that } \\
\text { promote learning. }\end{array}$ & 3.10 & Neutral & Moderate \\
\hline $\begin{array}{l}\text { 30. using community networks to publicize } \\
\text { school events and achievements }\end{array}$ & 3.17 & Neutral & Moderate \\
\hline $\begin{array}{l}\text { 31. maintaining stature and behavior that } \\
\text { upholds the dignity of teaching. }\end{array}$ & 3.00 & Neutral & Moderate \\
\hline $\begin{array}{l}\text { 32. allocating time for personal and } \\
\text { professional development (e.g. } \\
\text { participating in educational seminars and } \\
\text { workshops, enrolling in short-term courses } \\
\text { and post graduate programs, reading } \\
\text { educational materials regularly, and } \\
\text { engaging in educational research). }\end{array}$ & Neutral & Moderate \\
\hline $\begin{array}{l}\text { 33. manifesting personal qualities such as } \\
\text { enthusiasm, flexibility and caring and } \\
\text { articulating and demonstrating one's } \\
\text { personal philosophy of teaching. }\end{array}$ & 3.13 & Neutral & Moderate \\
\hline $\begin{array}{l}\text { 34. participating actively in professional } \\
\text { teacher organizations and keeping abreast } \\
\text { with recent developments in education. }\end{array}$ & 3.03 & Neutral & Moderate \\
\hline $\begin{array}{l}35 . \text { reflecting on the extent of the attainment of } \\
\text { students learning goals. }\end{array}$ & 3.30 & Neutral & Moderate \\
\hline Overall Mean & $\mathbf{3 . 2 2}$ & Neutral & Moderate \\
\hline$N=30$
\end{tabular}

Table 1 displays the level of stress of the multigrade teachers on various stressors.

The results reveal that almost all (33 out of 35) stressors were rated neutral by the multigrade teachers described as moderate stress. It indicates that despite the tasks and challenges encountered by the teachers in the practice of their profession, they can still manage to withstand the difficulties they face every day going to and in the workplace.

Stressors 1 to 5 are all pertained to the tasks of teachers as positive and powerful role models in the school. Looking at the results, they described these stressors as manageable tasks. It validates that teachers are already used to abide with the mandates required by the Constitution on the maintenance of dignity and reputation in and out their work stations (Code of Ethics for Professional Teachers, 1997). The provisions of this law requires teachers should to abide with the highest standard of ethical and moral philosophies.

Stressors 6 to 10 can be attributed to the role of teachers in creating a conducive classroom environment for the learners. The results display that four (4) of its stressors were rated neutral by the multigrade teachers. It means that teachers can able to withstand the pressures of providing a conducive learning space in the multigrade setting where they are in. It can be further gleaned that teachers wherever they are, can still manage to maintain a positive social 
and psychological environment considering that learning styles vary from one learner to another. This further supports that though teachers are being placed in these settings, they can manageably facilitate the individual needs of their learners (Little, 2006).

Stressors 11 to 15 can all be summarized as the tasks of teachers in addressing the diverse learning needs of the learners in school with utmost sensitivity. The results disclose that teachers' stress in all five (5) indicators are neutral in terms of responding to issues and concerns about the individual differences of learners (e.g. background, behavior, abilities, and upbringing). This indicates that teachers can bridge gaps between learners even there are complexities and dilemmas in the management of diversity. These peculiarities are not only limited to ethnicity and language but also to subcultures within the class possessing even more distinctive characteristics and psychological make-up (Banks \& Banks, 2009).

Meanwhile, stressors 16 to 20 can be affiliated to the role of teachers in providing suitable and contextualized learning programs and appropriate textual and visual devices for the learners to meet desired curriculum goals. Teachers are neutral in 4 of its stressors but they agree that they experience stress in selecting appropriate teaching methods, learning activities, and instructional devices to the learners $(M=3.53)$. It can be drawn from the results that teachers can generally adapt to the challenges of differentiated instruction to address the learning needs of the pupils of different ages. It only proves that multigrade teachers can manage to surpass the impediments of meeting the needs of his or her class with very unique composition when it comes to suitable teaching methodologies and activities elaborated by Ryder (2009).

Consequently, stressors 21 to 25 can be all about the task of teachers in using assessment data, integrating assessment procedures and reporting learners' progress to improve instruction and class achievement. All stressors were rated neutral by multigrade teachers which means that they can manage to deal with assessments tasks including preparation of quizzes and examinations, recording of scores, and evaluating the scores. It can be further noted from the result that despite changes in assessment modes implemented by the Department of Education, teachers can still manage to adjust and comply in multigrade settings (Dysthe, 2006; Little 2006).

Stressors 26 to 30 can be condensed to the idea of the task of teachers in building connections with school stakeholders to support school programs for possible funding and procurements of physical facilities and learning resources for utilization by learners. Results 
unfold that teachers meet moderate stress levels. It can be gleaned that teachers can respond to the challenge of maintaining sustainable networks with non-government organizations and foundations to provide the needs of the learners in multigrade settings. Despite the fact that they are least prioritized and insufficiently provided by the Department of Education, they managed to maintain these partnerships to support school operations (Department of Education, 2011).

Finally, stressors 31 to 35 are regards to the role of teachers to undergo professional development to improve his or her teaching skills. A moderate level of stress in all stressors among multigrade teachers is gained. This implies that teachers find concern for professional growth and improvement as manageable tasks. Inspite of the challenges posed by Bilbao et. al., (2012), multigrade teachers are still able to submit themselves to the continuing call for professional improvements to meet desired learners' learning goals.

Overall, the stress of multigrade teachers is at "normal" level described as moderate level $(M=3.22)$. This indicates that multigrade teachers can still manage to deal the different stressful circumstances that they may encounter in multigrade settings. Though most of stressors were described manageable by multigrade teachers, stressors pertaining to dealing with learners' behavioral problems and the selection of appropriate teaching methodologies, learning activities and resources obtained high scores (where $M=3.67 ; 3.53$, respectively). This could be attributed to the reason that behaviors issues of parents in multigrade class vary acrss ages in terms of interest, attention span, attitude, and learning styles. This corroborates the idea that the heightening challenge of learners' troublesome behavior displayed in the class is a major factor of stress (Morgan \& Craith, 2015). Classroom management in multigrade settings has long been a problem and a challenge for school stakeholders (SEAMEO INNOTECH, 2011). Meanwhile, selection of developmentally appropriate teaching methodologies and learning activities for multigrade learners are also issues encountered by multigrade teachers in these settings. This includes complex curriculum and lesson planning, subject combinations, and overcrowding of learning competencies as a result of combining all learners of multi-ages in one classroom (Msimanga, 2019). This proves that these two stressors are highly stressful tasks for multigrade teachers.

The overall result of this study is the same with the study of Roxas (2009) on regular teacher participants where he found out that stress is at "normal" level and they usually experience stress in the workplace but can just withstand the challenges of stressful events. The study of Eres and Atanasoska (2011) also unfolded that public elementary teachers in 
Macedonia reported moderate levels of stress at work.

Table 2. Professional Satisfaction of Multigrade Teachers

\begin{tabular}{|c|c|c|c|}
\hline Indicator & WM & Description & $\begin{array}{c}\text { Verbal } \\
\text { Description }\end{array}$ \\
\hline $\begin{array}{l}\text { 1. I find my profession rewarding, } \\
\text { fulfilling, and satisfying. }\end{array}$ & 3.70 & Often & High \\
\hline $\begin{array}{l}\text { 2. The profession and the working } \\
\text { environment is satisfying. }\end{array}$ & 3.33 & Sometimes & Medium \\
\hline $\begin{array}{l}\text { 3. I have a quality relationship with my } \\
\text { school head/principal which supports } \\
\text { me in accomplishing my teaching tasks. }\end{array}$ & 4.13 & Often & High \\
\hline $\begin{array}{l}\text { 4. I have higher degree of fulfilment in } \\
\text { multigrade teaching. }\end{array}$ & 3.67 & Often & High \\
\hline $\begin{array}{l}\text { 5. I am satisfied with the balanced works } \\
\text { in triangle to school administrator, } \\
\text { pupils and parents. }\end{array}$ & 3.70 & Often & High \\
\hline $\begin{array}{l}\text { 6. I am able to use my talents in teaching } \\
\text { and I have a regular and timely feedback } \\
\text { on how I am doing. }\end{array}$ & 3.77 & Often & High \\
\hline $\begin{array}{l}\text { 7. I find multigrade teaching important and } \\
\text { meaningful. }\end{array}$ & 3.90 & Often & High \\
\hline $\begin{array}{l}\text { 8. I am receiving just compensation for my } \\
\text { profession. }\end{array}$ & 3.80 & Often & High \\
\hline $\begin{array}{l}\text { 9. I am satisfied with the working } \\
\text { environment particularly the classroom, } \\
\text { office, equipment and facilities. }\end{array}$ & 3.43 & Sometimes & Medium \\
\hline $\begin{array}{l}\text { 10. I am satisfied with the school policies, } \\
\text { administration and procedures. }\end{array}$ & 3.63 & Often & High \\
\hline $\begin{array}{l}\text { 11. The quality of the physical environment } \\
\text { is satisfying. }\end{array}$ & 3.10 & Sometimes & Medium \\
\hline $\begin{array}{l}\text { 12. The day to day classroom and school } \\
\text { activities are fulfilling. }\end{array}$ & 3.57 & Often & High \\
\hline $\begin{array}{l}\text { 13. I have an adequate time for my lesson } \\
\text { planning and preparation for instruction. }\end{array}$ & 3.60 & Often & High \\
\hline $\begin{array}{l}\text { 14. The school principal consistently uses } \\
\text { both verbal and nonverbal forms of } \\
\text { communications to pass messages to } \\
\text { teachers. }\end{array}$ & 4.00 & Often & High \\
\hline $\begin{array}{l}\text { 15. Multigrade teaching gives me a feeling } \\
\text { of personal accomplishment. }\end{array}$ & 4.00 & Often & High \\
\hline $\begin{array}{l}\text { 16. Our Learning Action Cell (LAC) session } \\
\text { helps us improve our teaching skills. }\end{array}$ & 4.03 & Often & High \\
\hline $\begin{array}{l}\text { 17. I am satisfied with the seminars and } \\
\text { trainings that help us implement } \\
\text { multigrade classes. }\end{array}$ & 4.07 & Often & High \\
\hline
\end{tabular}




\begin{tabular}{llll}
\hline $\begin{array}{l}\text { 18. I am satisfied with the educational } \\
\text { programs which support us implement } \\
\text { multigrade classes. }\end{array}$ & 3.73 & Often & High \\
\hline $\begin{array}{l}\text { 19. Our principal consistently provides } \\
\text { technical assistance which help us } \\
\text { accomplish our teaching tasks. }\end{array}$ & 3.70 & Often & High \\
$\begin{array}{l}\text { 20. I am satisfied with the incentives } \\
\text { provided by the department in teaching } \\
\text { multigrade classes. }\end{array}$ & 3.57 & Often & High \\
\hline \multicolumn{1}{c}{ Overall Mean } & $\mathbf{3 . 7 2}$ & Often & High \\
\hline
\end{tabular}

$N=30$

Table 2 displays the professional satisfaction of multigrade teachers. The data show that multigrade teachers often have a quality relationship with their school head which supports them in accomplishing their teaching tasks $(M=4.13)$; they are satisfied with the seminars and trainings which help them implement multigrade classes $(M=4.07)$; helps them improve their teaching skills through their Learning Action Cell sessions $(M=4.03)$. The trend of the results suggests that the multigrade teachers were mainly satisfied in the technical support of their principal and fellow teachers. The study of Gopalkrishnan (2009) showed that higher job satisfaction existed between teachers and their principal. It further revealed that teachers were much satisfied with their principal compared to other indicators of satisfaction. Similarly, in the 1999 Canadian study, researchers found that teachers who indicated good relationships with their colleagues tend to be highly satisfied with teaching (Li, Wright, Rukavina \& Pickering, 2008). Further, Zhongshan (2008) revealed that elementary teachers are more satisfied with their colleagues and principals.

However, the teachers are sometimes satisfied with the quality of physical environment $(M=3.10)$; the profession and working environment $(M=3.33)$; and the working environment particularly the classroom, office, equipment and facilities $(M=3.43)$. It can be obviously noted from the results that items in which the teachers got lowest satisfaction all pertained to the physical and working environment. This can be explained by the fact that multigrade schools are underserved with the provision of physical facilities. In the survey conducted by the Department of Education (2011) about the profile of the multigrade schools in the Philippines, multigrade teachers are deprived of having well-organized classrooms, flexible chairs and storage areas as not $100 \%$ of the surveyed schools have these. $90.50 \%$ of the surveyed schools have well-organized classrooms, $85 \%$ have flexible chairs and $74.50 \%$ have storage areas and claimed that most of these furniture pieces are five to ten years old which needs repair or replacement (37.50\%). Furthermore, the status of the working environment and the provision of physical amenities are said to be poor primarily because of the socio-economic disposition of the place where these schools are located.

As a whole, the professional satisfaction of teachers obtained a weighted mean of 3.72 described as often. The result of the study implies that teachers have positive, high level of appreciation or pleasure towards their work or professional experience. The trend shows that the multigrade teachers were mainly satisfied with the administrative and collegial support and least on physical and working environment.

The result has the same findings with the global studies of Bhandari and Patil (2009) and Demirtas (2010) who found out that elementary teachers generally display high level of job satisfaction. Meanwhile, in the local study of Usop, et. al (2013), they found out that public elementary teachers in the Division of Cotabato City are generally very satisfied with the work itself. 
Table 3. Relationship between Stress and Professional Satisfaction

\begin{tabular}{ccccc}
\hline $\begin{array}{c}\text { Variables } \\
\text { Correlated }\end{array}$ & r value & p value & $\begin{array}{c}\text { Extent of } \\
\text { Relationship }\end{array}$ & Remarks \\
\hline $\begin{array}{c}\text { Workload Stress } \\
\text { and Professional } \\
\text { Satisfaction }\end{array}$ & .192 & .308 & Negligible & $\begin{array}{c}\text { Not } \\
\text { Significant }\end{array}$ \\
\hline $\boldsymbol{N}=\mathbf{3 0}$ & & & &
\end{tabular}

Table 3 displays the relationship between two correlated variables. After the bivariate analysis, the result revealed that there is no significant relationship between the stress and professional satisfaction of multigrade teachers. This is evident in the $r$ value of .192 and $p$ value of .308 which is greatly more than the margin error of 0.05 .

This shows that stress may not necessary influence the professional satisfaction of multigrade teachers. Looking at the first and third results, it is noteworthy that teachers have high level of satisfaction due to manageable level of stress at work. Based on logical interpretation, it can be gleaned that stress may not be a significant factor that could affect satisfaction. There are other factors that affect their satisfaction.

In the same vein, the findings of the study further corroborate with Necsoi (2011), Chaplain (2008), Schwarzer and Hallum (2008) which identified that there is a negative correlation between workload stress and professional satisfaction. Academic tenure showed substantially greater professional satisfaction among them. Despite reports of high levels of teachers' workload stress, many teachers find personal satisfaction in their work.

\section{Conclusions}

Based on the findings of this study, it has been concluded that multigrade teachers have moderate level of stress and can cope with the stresses and strains of teaching. However, it is recommended that school heads may conduct seminar on handling behavior problems and selecting appropriate teaching methods, learning activities and instructional materials in teaching multigrade which teachers find as highly stressful tasks.

Moreover, it has also been found out that the multigrade teachers have high level of appreciation towards their work; however, it is recommended that stakeholders' forum should be conducted to address the needs of multigrade schools for a healthy physical and working environment.

Lastly, the stress of multigrade teachers has no influence to their professional satisfaction. Studies may be conducted to further test and probe the theory about the relationship between the two variables in other settings with wider scope. Situational analysis should also be conducted to study the high professional satisfaction of multigrade teachers.

Considering the limitation of this research focusing only on the association between stress and satisfaction, it will be more comprehensive to explore other factors as satisfaction is a composite result of many events that surround the workplace.

\section{References}

Asaloei, S. I., Wolomasi, A. K. \& Werang, B. R. (2020). Work-related stress and performance among primary school teachers. International Journal of Evaluation and Research in Education, 9 (2), 352-358. https://doi.org/10.11591/ijere.v9i2.20335

Bhandari, R. A. \& Patil, N. H. (2009). Job satisfaction of women teachers. Edutracks, 8(11), 4244.

Banks, J. A. \& Banks, C. A. M. G. (2009). Multicultural education: Issues and perspectives. 
( $7^{\text {th }}$ ed.). Hoboken, N. J: Wiley. p. 43.

Bemana, S. \& Moradi, Hassan \& Ghasemi, M. \& Taghavi, S.M. \& Ghayoor, A.H. (2013). The relationship among job stress and job satisfaction in municipality personnel in Iran. World Applied Sciences Journal, 22 (2), 233-238. https://doi.org/10.5829/idosi.wasj.2013.22.02.3640

Bilbao, P., Corpuz, B., Llagas, A. \& Salandanan, G. (2012). The teaching profession. ( $2^{\text {nd }}$ ed.). Lorimar Publishing, Inc.

Chaplain, R. P. (1995). Stress and job satisfaction: a study of English primary school teachers, Educational Psychology, 15(4) 473-489. https://doi.org/10.1080/0144341950150409

Day, C., Sammons, P., Stobart, G., Kington, A. \& Gu, Q. (2007). Teachers Matter: Connecting Lives, Work, and Effectiveness. Maidenhead: Open University Press.

Department of Education (2011). Profile of multi-grade schools in the Philippines. Retrieved from http.//seameo-innotech.org

De Nobile, J.John \& Mc Cormick, J (2008). Job satisfaction and occupational stress in Catholic primary schools. Educational Management Administration and Leadership, 36 (1), 101-122. https://doi.org/10.1177/1741143207084063

Enayati, T., Movahedian, M. \& Zameni, F. (2016). Classroom management strategies of multigrade schools with emphasis on the role of technology. Interdisciplinary Journal of Virtual Learning in Medical Sciences, 7 (2), 165-179. https://doi.org/10.5812/ijvlms.12161

Eres \& Atanasoska (2011). Occupational stress of teachers: A comparative study between Turkey and Macedonia. International Journal of Humanities and Social Science, 1 (7), 59-61. Available: http://www.ijhssnet.com/journals/Vol._1_No._7_[Special_Issue_June_2011]/9.pdf

Gopalkrishnan, V. (2009). Determinants of job satisfaction of self-financing college teachers. Journal of Community Psychology and Research, 26 (3), 300-310.

Harish, K. A. \& Prabha, B. J. (2019). Performance on the work-related stress and job contentment of primary school teachers of government and private sectors. International Journal of Recent Technology and Engineering, 8 (2), 143-147. https://doi.org./ 10.35940/ijrte.B1027.0782S219

Jordaan, V. A. (2006). Facilitators' course on multi-grade teaching. Facilitators guide with resources. Bloemfontein, South Africa: Free State Department of Education.

Kaur, S (2011). Job satisfaction and occupational stress among school teachers: A correlation study. International Referred Research Journal, 3 (32), 49-50. https://doi.org/10.5296/jsr.v5i1.5426

Kayastha, D. P. \& Kayastha, R. (2012). A study of job satisfaction among teachers, higher secondary school of Nepal. International Journal of Evaluation and Research in Education, 01 (01), 41-44. ISSN: 2252-8822

Kyriacou, C., \& Chien, P. (2004). Teacher stress in Taiwanese primary school. Journal of Education Enquiry, 5 (2), 86-104. Available: https://www.researchgate.net/publication/237285544

Li, Wright, Rukavina \& Pickering (2008). Measuring students' perceptions of personal and social responsibility and its relationship to enjoyment in urban physical education. Journal of Teaching in Physical Education, 27, 167-178. https://bit.ly/31yrlz7

Little, A. W. (2001). Multigrade teaching: Towards an international research and policy agenda. International Journal of Educational development, 21 (6), 477-479. 
https://doi.org/10.1016/S0738-0593(01)00010-4

Little, A. W. (2006). Education for all and multigrade teaching: Challenges and opportunities. Springer Science \& Business Media. Available: https://goo.gl/ryxEWp

Little, A. W., Pridmore, P., Bajracharya, H. \& Vithanaphathivana, M. (2007). Learning and teaching in multigrade settings. [Online]. Available: https://bit.ly/35k9X2M

Lomax, R. \& Li, J. (2013). Correlational research: Definitions of quantitative methods of research. Retrieved from http://goo.gl/v5A3y7

Morgan, M. \& Craith, D. C. (2015). Workload, stress and resilience of primary teachers: Report of a survey of INTO members. [Online]. Available: https://www.into.ie/app/uploads/2019/07/WorkloadReport_Sept15.pdf (September, 2015).

Msimanga, M. R. (2019). Managing the use of resources in multi-grade classrooms. South African Journal of Education, 39 (3), 1-9. https://doi.org/10.15700/saje.v39n3a1599

Necsoi DV (2011) Stress and Job Satisfaction among University Teachers. International Conference of Scientific Paper AFASES, 26-28 May, Brasov, 320-325.

Parsa,S., Alizadeh,S., \& Kasraie, S. (2013). The investigation of relationship between job stress and job satisfaction and responsiveness (accountability) of teachers in high schools of Urmia city. International Journal of Educational Science and Research, 03 (01), 89-98. ISSN: 22496947

Rotas, E. E. \& Cahapay, M. B. (2020). Workload stress and results-based performance of multigrade teachers. Journal of Studies in Education, 10 (2), 68-80. https://doi.org/10.5296/jse.v10i2.16874

Roxas, C. (2009). Stress among public elementary school teachers. Journal of Research Studies in Psychology, 1 (4), 86-108. https://doi.org/10.1.1.683.3910

Schwarzer, R. \& Hallum, S. (2008). Perceived teacher self-efficacy as a predictor of job stress and burnout. Applied Psychology, 57 (1), 152-171. https://doi.org/10.1111/j.14640597.2008.00359.x

SEAMEO INNOTECH (2011). Profile of multi-grade schools in the Philippines [Online] Available:http://www.seameo-innotech.org/wpcontent/uploads/2014/01/PolRes_ProfileofMultigradeSchoosInThePhilippines.pdf

Tehseen and Ul Hadi (2015). Factors influencing teachers' performance and retention. Mediterranean Journal of Social Sciences, 6 (01), 233-244. https://doi.org/10.5901/mjss.2015.v6n1p233

Usop, Askandar, Kadtong \& Usop (2013). Work performance and job satisfaction among teachers. International Journal of Humanities and Social Science, 03 (05). Available: http://www.ijhssnet.com/

Veenman, S. (1995). Cognitive and noncognitive effects of multigrade and multi-age classes: A best-evidence synthesis. Review of Educational Research, 65 (4), 319-381. https://www.jstor.org/stable/1170701

Vicente, R. F. (2012). The challenges of multigrade teaching. [Online]. Available: https://www.slideshare.net/Pilmathe2001/the-challenges-of-multigrade-teaching (July 11, 2012).

Wang, L. (2012). A survey on work stress and job satisfaction of primary and junior high school teachers. International Conference on Technology and Management Lecture Notes in 
Information Technology, 21.

Weiss, H. \& Copranzano, R. (1996). Affective events theory: A theoretical discussion of the structure, cause and consequences of affective experiences at work. Research in Organizational Behavior, 18, 1-74. Available: https://www.researchgate.net/publication/228079335

Zhongshan, Z. (2007). Study of job satisfaction among elementary school teachers in Shanghai. Chinese Education and Society, 40 (5), 40-46. https://doi.org/10.2753/CED1061-1932400505

\section{Funding}

This is a self-conducted research through the expense of the author. 